\section{on \\ Effect of Bio-Luminescent Bacteria on Organoleptic Qualities of Fishes from Cochin Backwaters}

The studies on the luminescent bacteria from Indian waters are scanty. RAMAMURTHY identified parasitic luminescent Aeromonas from porto Novo waters of Bay of Bengal. ${ }^{1)}$ Jayabalan, Dhevendran \& RamAMURTHY isolated symbiotic bio-luminescent bacteria in the light organs of silver bellies. ${ }^{2}$ )

KRISHNAMURTHY isolated free living luminescent bacteria of Nesseria in the head region of prawns from Cochin backwaters of Arabian Sea. ${ }^{3 \text { ) }}$

The present study deals with the presence of enteric luminescent bacteria-Photobacterium and Lucibacterium in two of the commercial backwater fishes viz. Gerres sp. and Mugil sp. The aim of the present study is to investigate whether the presence of luminescent bacteria in the backwater food fishes can effect the organoleptic qualities of fish products.

The investigation carried out for about four months in Munambam estuary situated about $20 \mathrm{~km}$ of Cochin $\left(76^{\circ} 12-13^{\prime} \mathrm{E}, 09^{\circ} 56^{\prime} \mathrm{N}\right)$. Two species of fishes viz. Gerres setifer and Mugil cephalus were caught from the estuary from Chinese dip nets.

The luminescent colonies were observed in the dark after 48 hours of incubation at room temperature $28 \pm$ $2^{\circ} \mathrm{C}$. Those colonies which emitted greenish bright luminescence were picked up and transferred to sea water and distilled water agar slants for culturing. These were again streaked and restreaked for pure culture. 24 cultures thus prepared were studied for their morphological and biochemical properties and their systematic position was determined with the aid of Bergy's Manual of Determinative Bacteriology.4) Methods suggested by HeNDrie et al. were also followed. ${ }^{\text {s) }} 19$ strains of Photobacterium and 5 strains of Lacibacterium were isolated (Table 1). All the 24 strains of luminescent bacteria were found to liquify gelatin. However, a differential variations of liquifaction of gelatin was observed. The strains of Lucibacterium liquified gelatin more rapidly than that

Table 1. Total plate counts of bacterial colony and the corresponding luminescent bacterial count in the two selected species of fishes and its environment

\begin{tabular}{lrcc}
\hline & $\begin{array}{c}\text { TPC/ } \\
\text { gram/ } \\
\text { ml } \times 10^{4}\end{array}$ & $\begin{array}{c}\text { No. of } \\
\text { Photo- } \\
\text { bacterium } \\
\text { colonies }\end{array}$ & $\begin{array}{c}\text { No. of } \\
\text { Luci- } \\
\text { bacterium } \\
\text { colonies }\end{array}$ \\
\hline Mud & 22 & - & - \\
Water & 184 & - & - \\
Gerres Muscle & 38 & - & - \\
Gerres Gill & 3 & - & - \\
Gerres Stomach & 24 & 7 & - \\
Gerres Intestine & 202 & - & - \\
Mugil Muscle & 47 & - & - \\
Mugil Gill & 32 & 3 & 5 \\
Mugil Stomach & 9 & - & - \\
Mugil Intestine & 31 & 9 & - \\
\hline
\end{tabular}

of Photobacterium. Indole production and hydrolisation of starch were also observed as in the case of Lucibacterium.

The percentage of luminescent bacterial strains in the gut of these fishes were high when compared to that of gills. The maximum population of luminescent bacteria occurred in Mugil cephalus when they were found in the gills and intestine. Whereas in the case of Gerres setifer, luminescent bacteria occurred only in the stomach and they were not reported in the surrounding environment. There was no sign of luminescent bacteria in the muscle of both fishes. In general, the occurrence of these luminescent bacteria in the intestinal content of fishes shows that these strains prefer an enteric habitat.

The occurrence of luminescent bacterial strains were more in the region of higher salinity and $\mathrm{pH}$ of the backwater environment. Temperature did not seem to have any effect on the occurrence of luminescent bacteria. The present investigation confirms the earlier studies of KRISHNAMURTHY ${ }^{\text {s) }}$ that the presence of luminescent bacteria in prawns do not affect the organoleptic qualities such as colour of the skin and flesh, flavour and texture of the meat. 14 frozen fillets of the above two species of fishes were smeared with $5 \%$ to $10 \%$ of luminescent bacteria in respect of total plate count and were preserved at a temp. of $-17^{\circ} \mathrm{C}$ in the cold storage for about 24 to 48 hours. Observation on these fillets with above said levels of contamination of luminescent bacteria after 48 hours revealed that it did not show any variations from the fresh fillets in respect of organoleptic qualities. Total plate count before and after storing in the cold storage were noted as $24 \times 10^{4}$ and $18 \times 10^{4}$ respectively.

It was also observed that the fresh fish of the same species in the experimental tanks which harbour $10 \%$ to $15 \%$ luminescent bacteria in muscle, gill, stomach and intestine did not show any diseased symptoms even after 2 months and no change in the \% of contamination during culture.

We are grateful to Dr. V. D. Ramamurthy, Deputy Director for encouragements and suggestions. Thanks are due to Dr. C. T. SAMuel, Dean and Head of the Department of Industrial Fisheries, University of Cochin, for his comments on the manuscript.

Received June 15, 1981

V. K. DEX and V. KRISHNAMURThy

Inspection Laboratory, The Marine Products Export Development Authority, Willingdon Island, Cochin682003 , S. India.

\section{References}

1) V. D. Ramamurthy: Curr: Sci, 42, 624 (1973).

2) N. Jayabalan, K. Dhevendran, and K. RamaMURTHY: Curr. Sci, 47, 648-649 (1978).

3) V. Krishnamurthy: Curr. Sci., 49, 36 (1979).

4) "Bergy's Manual of Determinative Bacteriology" (ed. by R. E. Buchanan and N. E. GibBons), 8th ed., Williams \& Wilkins, Baltimore, pp. 349351 (1974).

5) M. S. Hendrie, W. Hodgkiss, and J. M. Shewan: J. Gen. Microbiol., 64, 151-169 (1970). 